\title{
Re-Use of Established Drugs for Anti-Metastatic Indications
}

\author{
Frank Entschladen 1,2,*, Dane A. Thyssen ${ }^{1}$ and David W. Drell ${ }^{1}$ \\ Received: 21 November 2015; Accepted: 8 January 2016; Published: 12 January 2016 \\ Academic Editor: Ritva Tikkanen \\ 1 MetaVì Labs Inc., 16238 Ranch Road 620 North, Suite F-347, Austin, TX 78717, USA; \\ athyssen@metavilabs.com (D.A.T.), ddrell@metavilabs.com (D.W.D.) \\ 2 Faculty of Health—School of Medicine, Witten/Herdecke University, Alfred-Herrhausen-Straße 50, \\ 58448 Witten, Germany \\ * Correspondence: fentschladen@metavilabs.com or entschladen@uni-wh.de; Tel.: +49-2045-413-3708; \\ Fax: +49-2045-413-3707
}

\begin{abstract}
Most patients that die from cancer do not die due to the primary tumor but due to the development of metastases. However, there is currently still no drug on the market that specifically addresses and inhibits metastasis formation. This lack was, in the past, largely due to the lack of appropriate screening models, but recent developments have established such models and have provided evidence that tumor cell migration works as a surrogate for metastasis formation. Herein we deliver on several examples a rationale for not only testing novel cancer drugs by use of these screening assays, but also reconsider established drugs even of other fields of indication.
\end{abstract}

Keywords: cancer; metastasis; cell migration; drug screening

\section{New Test Methods for Established Drugs Can Reveal Additional Indications}

The development process of a new drug from target identification to approval is time-consuming and expensive in any type of medical indication. Therefore, when a drug, once approved, turns out to be well-tolerated and effective, it is mandatory to further explore the profile of efficacy and side effects. On the one hand, possible risks of unwanted side effects have to be monitored in order to protect the patients. On the other hand, there may be some beneficial effects aside from the primary indication, which can only be detected under certain circumstances, e.g., in special subgroups of patients, in combination with other drugs or in long-term use. These beneficial effects may lead to a second or extended approval and maximize the profit for both patients and companies. This issue of drug repositioning especially applies to the oncological field, since the success rate for new drugs is particularly low as compared to non-oncological indications [1]. Even established drugs of other fields of medical indications may be identified as being effective in cancer treatment in the future, as will be discussed below on recent examples.

In order not to be dependent on occasional observations, how can such a new application be tested systematically? New assays for drug testing may reveal further forms of action not only for new drugs, but also for old ones, and may open new fields of applications. The European Medicines Agency (EMA) has claimed new test methods for drug development: "Until non-clinical models with good predictive properties have been defined... the absence of such models is considered to constitute the greatest hurdle for efficient drug development within the foreseeable future." [2]. This applies not only to new drugs, but, in light of drug repurposing, even old drugs should by tested by means of such new models. These new models comprise tumor cell functions that have not been tested before, e.g., angiogenesis and migration [3], but may also apply to the elaboration of conventional cytotoxicity tests, e.g., by the use of spheroid models instead of classic cell culture. However, herein we focus on the example 
of anti-metastatic drugs and on tumor cell migration as its valid surrogate. Metastasis formation is the most pernicious event in the course of a cancer disease and is decisive for the patients' survival probability. Although over $90 \%$ of those patients that die from cancer die due to the development of metastases [4], there is still no anti-metastatic drug on the market. The establishment of tumor cell migration assays facilitates the detection of such an anti-metastatic effect. In this regard Patricia Steeg has rendered: "...drug development continues to rely heavily on short-term reductions in the size of primary tumors. These data suggest that compounds validated in this manner may not work on metastatic disease, and that compounds with antimetastatic efficacy may not be validated in tests based on reduction of primary tumor size." [5]. In this line of argumentation, Mike Fernandes and his colleagues further ask if size-based response criteria might be an anachronism [6]. Alexandra Zimmer and Patricia Steeg have nicely summarized data on metastasis prevention of existing cancer therapeutics including receptor and non-receptor kinase inhibitors [7].

\section{Examples of Drug Repurposing in Oncology}

To date, the by far most striking discovery in the context of drug repurposing in oncology is the anti-metastatic function of beta-blockers [8]. Stimulated by results provided by in vitro drug testing systems [9-11], and confirmed by mice experiments [12], several retrospective patient studies have delivered proof for an anti-metastatic effect in various types of solid tumors, i.e., breast, ovarian, prostate, colorectal, lung, liver, melanoma [13-29]. The in vitro drug testing systems that initially led to this development were migration analyses, which are currently not a standard drug screening method in oncology, but may constitute such a new model as requested by the EMA. The function of beta-blockers has been identified by a three-dimensional, collagen-based migration model of single cells [30], but several other tumor cell migration assays have been established that may turn out to be qualified as novel drug screening methods [31-33].

The benefits of drug repurposing in oncology have been recently discussed in detail by Pan Pantziarka and his colleagues, providing a list of six generic drug candidates to be tested for oncology application in clinical trials in the ReDo project, namely Mebendazole, Nitroglycerin, Cimetidine, Clarithromycin, Diclofenac and Itraconazole [34]. In addition to these advanced projects, there are several further candidates for such a possible use or re-use of established drugs in oncology. A recent example is the GABA-B receptor agonist baclofen, which was initially approved for the treatment of epilepsia. Current research on the role of GABA in cancer provided conflicting results: some reports support the view that the GABA-B receptor may have a tumor-promoting effect in prostate and breast cancer [35,36], whereas Ortega's review suggests an inhibitory effect on tumor metastasis in various types of cancer [37]. Neman and colleagues provided the most striking evidence on human tissue samples of breast cancer that the GABAergic system is involved breast-to-brain metastasis formation [38], showing that the GABAergic system is a valid target and existing drugs on the involved receptors may be considered for an oncological application. Another very interesting example is thalidomide. This drug is supposed to have immunomodulatory effects that inhibit angiogenesis in myeloma [39], whereas it has previously been approved as a sedative but sadly turned out to have serious teratogenic side effects [40]. Nevertheless, these new findings on angiogenesis inhibition stimulated the development of novel thalidomide analogues as immunomodulatory and anti-angiogenic drugs [41].

Further neurotransmitters with a proven function in breast cancer cell migration, in addition to the aforementioned adrenergic and GABAergic axes, are dopamine and substance $\mathrm{P}$ acting via the D2 and neurokinin-1 receptors, respectively [10]. These effects are inhibited by the respective drugs metoclopramide for the D2 receptor and L-733,060 for the neurokinin-1 receptor. Furthermore, engagement of the inhibitory cannabinoid receptors by its physiological agonist anandamide reduced tumor cell migration of colon cancer cells as well [42]. Therefore, there are several examples of neurotransmitter function in tumor cell migration, and one might speculate that further clinically established agonists or antagonists for neurotransmitters, as listed in Table 1, can have a clinical 
effect in cancer progression as well. We have found some effects of neurotransmitters on breast cancer cell migration [9], and therefore suggest (re-)evaluating these drugs by in vitro test systems and retrospective patients studies in parallel for a potential role in cancer.

Table 1. Neurotransmitter agonists and antagonists.

\begin{tabular}{|c|c|c|}
\hline \multicolumn{3}{|c|}{ Proven Effect on Cancer Cells } \\
\hline$\underline{\text { Substance }}$ & Current indication & Receptor \\
\hline Propranolol & hypertension & $\beta 1 / \beta 2$-adrenoceptor-antagonist \\
\hline Baclofen & epilepsia & GABA-B agonist \\
\hline Metoclopramide & nausea & dopamine D2 antagonist \\
\hline $\mathrm{L}-733,060$ & anxiety, depression & neurokinin-1 antagonist \\
\hline \multicolumn{3}{|c|}{ Further Drugs to be Evaluated } \\
\hline$\underline{\text { Substance }}$ & Current indication & Receptor \\
\hline Iosartan & hypertension & angiotensin AT1 antagonist \\
\hline Ipratropium & asthma & anticholinergic \\
\hline Montelukast & asthma & leukotriene D4 antagonist \\
\hline Ioratadine & allergies & histamine $\mathrm{H} 1$ antagonist \\
\hline Famotidine & ulcers & histamine $\mathrm{H} 2$ antagonist \\
\hline Olanzapine & schizophrenia & dopamine D1/D2/5-HT2 \\
\hline Risperidone & psychosis & dopamine D2/5-HT2A \\
\hline Sumatriptan & migrane & serotonin $5-\mathrm{HT} 1$ agonist \\
\hline Fentanyl & pain & opioid agonist \\
\hline
\end{tabular}

\section{Selection of Candidates by Their Action in Signal Transduction}

The aforementioned examples have provided evidence that old drugs can successfully be reconsidered for an oncological indication. By means of tumor cell migration assays as novel drug screening models, new or existing drugs can be tested for anti-metastatic effects, and we have exemplarily investigated two existing oncology drugs that were, from their mode of action, likely candidates. These are Bayer's multi-receptor tyrosine kinase (RTK) inhibitor Regorafenib (Figure 1A) and Novartis' phosphatidyl-inositol-3 kinase (PI3K) inhibitor BKM120 (Buparlisib; Figure 1B). We had selected these drugs since they are both small molecule kinase inhibitors with a known involvement in the signal transduction that regulates tumor cell migration [43]. RTKs are the receptors for growth factors and other members of the cytokine super-family, which are known regulators of migratory activity. With regard to cancer, the epithelial growth factor receptor (EGFR) has probably received the most interest, especially the family member HER2 (also known as erbB2). HER2-positive tumors tend to be more aggressive than other types of breast tumors [44]. The PI3K is a downstream element in signal transduction, directly activated by RTKs [43]. The PI3K generates the two second messengers, diacylglycerol and inositol-trisphosphate, by the enzymatic breakdown of phosphatidyl-inositol-bisphosphate. Inositol-trisphosphate induces a release of calcium from intracellular stores, and diacylglcerol is an activator of the protein kinase C. Both second messengers, in concert, regulate actin polymerization, actin-binding molecules, and non-muscle myosin II activity [43], whereas the sole activation of the protein kinase $C$ is a strong inducer of tumor cell migration [45].

We have used the same cell migration assay that was previously used for the discovery of the anti-migratory effect of beta-blockers [9-11]. This assay is a single-cell migration assay, with the cells being embedded into a three-dimensional collagen matrix close to physiological conditions. As shown in Figure 1, both of the investigated substances significantly inhibited tumor cell migration at concentrations that are relevant for patients' treatment (the concentrations were calculated on the basis of the clinically applied doses). Thus, these results would support the claim of having an anti-metastatic effect for these drugs. 
A
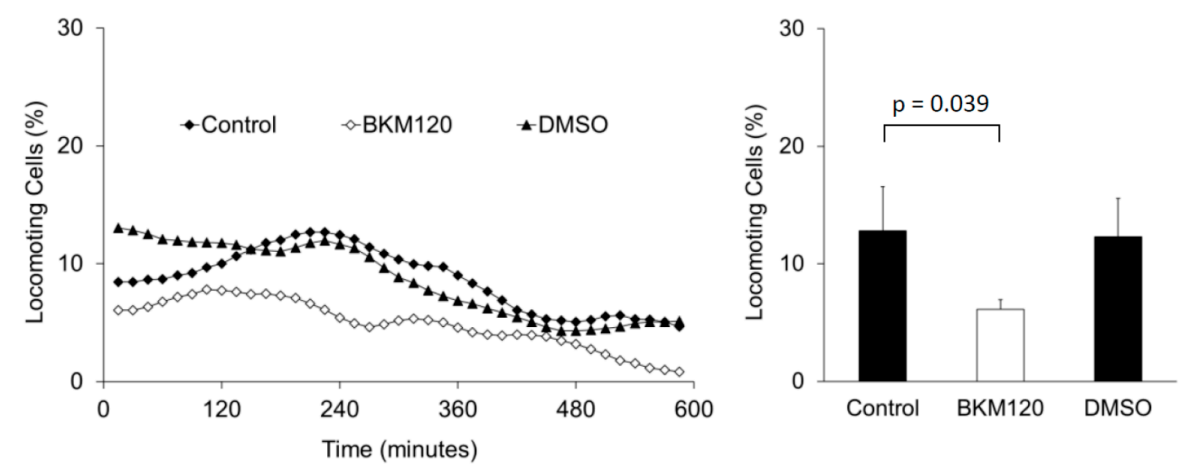

B

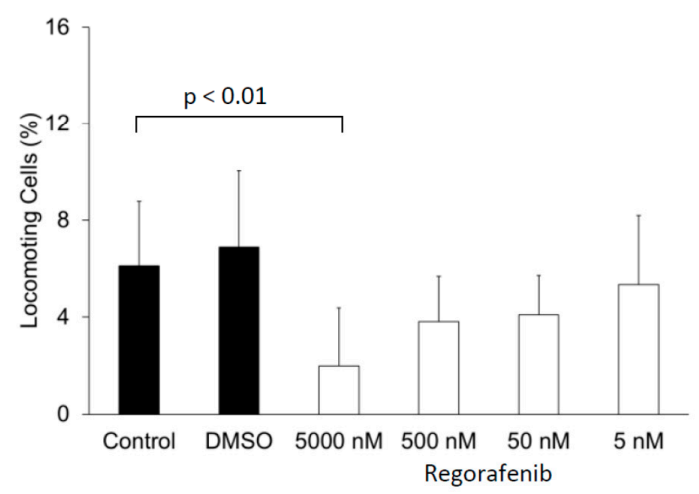

Figure 1. Cell migration was performed using the human estrogen receptor-positive, luminal-like breast carcinoma cells MCF-7 with regard to BKM120 ( $n=3 ; \mathbf{A})$; and the human epitheloid pancreatic cancer cell line PANC-1 with regard to Regorafenib $(n=7 ; \mathbf{B})$. Due to limited availability of material, only three experiments have been performed with one concentration for BKM 120. Both cell lines were obtained from the Cell Lines Service GmbH (Eppelheim, Germany). DMSO concentrations correspond to the highest concentration used to dissolve the substances. In (A), the left graph shows the time course of the migratory activity, the right graph displays the mean activities and standard deviations after four hours; In (B), the columns show the mean activities and standard deviations of the entire observation time of $10 \mathrm{~h}$.

For the analysis of the migratory activity, the $10 \mathrm{~h}$ observation period is subdivided into $15 \mathrm{~min}$ intervals. The term "locomoting cell" is defined as a cell which moved within a particular observation period (each period is marked in Figure 1A (left) by a symbol). The $y$-axis shows the locomoting cells as part of the entire observed population (in percent) for each of these intervals. For the column diagrams (A right and B), the average value of the locomoting cells of the observation intervals has been generated independently for each single experiment. The columns display the subsequently generated mean values and standard deviations of all experiments that have been performed. Please note, that the standard deviation appears to be higher in Figure 1B as compared to Figure 1A (right), since the overall activity of PANC-1 cells is lower than that of MCF-7 cells. In addition, in Figure 1B the entire observation period of $10 \mathrm{~h}$ has been chosen to generate the over-time average, which caused a higher inter-experimental deviation than the $4 \mathrm{~h}$ period of Figure 1A (right). For details on the analysis of migration parameters, please see Niggemann et al. [46].

\section{Conclusions}

We have shown herein, on the example of tumor cell migration, that in addition to the search for new drugs by means of conventional preclinical test systems, the establishment of novel test systems 
can help not only the development of new drugs but is also valuable for discovering further functions of existing drugs. The advantages of the latter are (i) for the patients for whom established drugs are already clinically characterized and thus have a known profile of safety and action, (ii) for the pharma companies for whom an extension of applications increases the drugs' value. With regard to anti-metastatic drugs, it has turned out, on the example of beta-blockers, that cell migration is a valid preclinical test system for their identification. In this regard, the knowledge of the molecular signal transduction that regulates tumor cell migration provides a systematic approach for the selection of anti-metastatic drug candidates.

Author Contributions: All authors jointly collected the data and created the draft. Final manuscript preparation was performed by F.E.

Conflicts of Interest: All authors are shareholders of MetaVì Labs.

\section{References}

1. Walker, I.; Newell, H. Do molecularly targeted agents in oncology have reduced attrition rates? Nat. Rev. Drug Discov. 2009, 8, 15-16. [CrossRef] [PubMed]

2. European Medicines Agency; Oncology Working Party. Guideline on the Evaluation of Anticancer Medicinal Products in Man; European Medicines Agency: London, UK, 2011; p. 5.

3. Drell, T.L.; Zaenker, K.S.; Entschladen, F. Translational research in oncology: The need of additional in vitro preclinical testing methods for new drugs. Curr. Pharm. Des. 2012, 18, 3416-3420. [CrossRef] [PubMed]

4. Sporn, M.B. The war on cancer. Lancet 1996, 347, 1377-1381. [CrossRef]

5. Steeg, P.S. Tumor metastasis: Mechanistic insights and clinical challenges. Nat. Med. 2006, 12, 895-904. [CrossRef] [PubMed]

6. Fernandes, M.; Rosel, D.; Brabek, J. Translation in solid cancer: Are size-based response criteria an anachronism? Clin. Transl. Oncol. Off. Publ. Fed. Span. Oncol. Soc. Natl. Cancer Inst. Mex. 2015, 17, 1-10. [CrossRef] [PubMed]

7. Zimmer, A.S.; Steeg, P.S. Meaningful prevention of breast cancer metastasis: Candidate therapeutics, preclinical validation, and clinical trial concerns. J. Mol. Med. 2015, 93, 13-29. [CrossRef] [PubMed]

8. Nagaraja, A.S.; Sadaoui, N.C.; Lutgendorf, S.K.; Ramondetta, L.M.; Sood, A.K. Beta-blockers: A new role in cancer chemotherapy? Expert Opin. Investig. Drugs 2013, 22, 1359-1363. [CrossRef] [PubMed]

9. Drell, T.L.; Joseph, J.; Lang, K.; Niggemann, B.; Zaenker, K.S.; Entschladen, F. Effects of neurotransmitters on the chemokinesis and chemotaxis of mda-mb-468 human breast carcinoma cells. Breast Cancer Res. Treat. 2003, 80, 63-70. [CrossRef] [PubMed]

10. Lang, K.; Drell, T.L.; Lindecke, A.; Niggemann, B.; Kaltschmidt, C.; Zaenker, K.S.; Entschladen, F. Induction of a metastatogenic tumor cell type by neurotransmitters and its pharmacological inhibition by established drugs. Int. J. Cancer 2004, 112, 231-238. [CrossRef] [PubMed]

11. Masur, K.; Niggemann, B.; Zanker, K.S.; Entschladen, F. Norepinephrine-induced migration of sw 480 colon carcinoma cells is inhibited by beta-blockers. Cancer Res. 2001, 61, 2866-2869. [PubMed]

12. Palm, D.; Lang, K.; Niggemann, B.; Drell, T.L.; Masur, K.; Zaenker, K.S.; Entschladen, F. The norepinephrine-driven metastasis development of pc-3 human prostate cancer cells in balb/c nude mice is inhibited by beta-blockers. Int. J. Cancer 2006, 118, 2744-2749. [CrossRef] [PubMed]

13. Barron, T.I.; Connolly, R.M.; Sharp, L.; Bennett, K.; Visvanathan, K. Beta blockers and breast cancer mortality: A population-based study. J. Clin. Oncol. 2011, 29, 2635-2644. [CrossRef] [PubMed]

14. Botteri, E.; Munzone, E.; Rotmensz, N.; Cipolla, C.; de Giorgi, V.; Santillo, B.; Zanelotti, A.; Adamoli, L.; Colleoni, M.; Viale, G.; et al. Therapeutic effect of beta-blockers in triple-negative breast cancer postmenopausal women. Breast Cancer Res. Treat. 2013, 140, 567-575. [CrossRef] [PubMed]

15. De Giorgi, V.; Grazzini, M.; Gandini, S.; Benemei, S.; Lotti, T.; Marchionni, N.; Geppetti, P. Treatment with beta-blockers and reduced disease progression in patients with thick melanoma. Arch. Intern. Med. 2011, 171, 779-781. [CrossRef] [PubMed]

16. Diaz, E.S.; Karlan, B.Y.; Li, A.J. Impact of beta blockers on epithelial ovarian cancer survival. Gynecol. Oncol. 2012, 127, 375-378. [CrossRef] [PubMed] 
17. Grytli, H.H.; Fagerland, M.W.; Fossa, S.D.; Tasken, K.A. Association between use of beta-blockers and prostate cancer-specific survival: A cohort study of 3561 prostate cancer patients with high-risk or metastatic disease. Eur. Urol. 2014, 65, 635-641. [CrossRef] [PubMed]

18. Grytli, H.H.; Fagerland, M.W.; Fossa, S.D.; Tasken, K.A.; Haheim, L.L. Use of beta-blockers is associated with prostate cancer-specific survival in prostate cancer patients on androgen deprivation therapy. Prostate 2013, 73, 250-260. [CrossRef] [PubMed]

19. Lemeshow, S.; Sorensen, H.T.; Phillips, G.; Yang, E.V.; Antonsen, S.; Riis, A.H.; Lesinski, G.B.; Jackson, R.; Glaser, R. Beta-blockers and survival among danish patients with malignant melanoma: A population-based cohort study. Cancer Epidemiol. Biomark. Prev. 2011, 20, 2273-2279. [CrossRef] [PubMed]

20. Melhem-Bertrandt, A.; Chavez-Macgregor, M.; Lei, X.; Brown, E.N.; Lee, R.T.; Meric-Bernstam, F.; Sood, A.K.; Conzen, S.D.; Hortobagyi, G.N.; Gonzalez-Angulo, A.M. Beta-blocker use is associated with improved relapse-free survival in patients with triple-negative breast cancer. J. Clin. Oncol. 2011, 29, 2645-2652. [CrossRef] [PubMed]

21. Powe, D.G.; Voss, M.J.; Zaenker, K.S.; Habashi, H.O.; Green, A.R.; Ellis, I.O.; Entschladen, F. Beta-blocker drug therapy reduces secondary cancer formation in breast cancer and improves cancer specific survival. Oncotarget 2010, 1, 628-638. [CrossRef] [PubMed]

22. Wang, H.M.; Liao, Z.X.; Komaki, R.; Welsh, J.W.; O’Reilly, M.S.; Chang, J.Y.; Zhuang, Y.; Levy, L.B.; Lu, C.; Gomez, D.R. Improved survival outcomes with the incidental use of beta-blockers among patients with non-small-cell lung cancer treated with definitive radiation therapy. Ann. Oncol. 2013, 24, 1312-1319. [CrossRef] [PubMed]

23. De Giorgi, V.; Gandini, S.; Grazzini, M.; Benemei, S.; Marchionni, N.; Geppetti, P. Effect of beta-blockers and other antihypertensive drugs on the risk of melanoma recurrence and death. Mayo Clin. Proc. 2013, 88, 1196-1203. [CrossRef] [PubMed]

24. Jansen, L.; Hoffmeister, M.; Arndt, V.; Chang-Claude, J.; Brenner, H. Stage-specific associations between beta blocker use and prognosis after colorectal cancer. Cancer 2014, 120, 1178-1186. [CrossRef] [PubMed]

25. Nkontchou, G.; Aout, M.; Mahmoudi, A.; Roulot, D.; Bourcier, V.; Grando-Lemaire, V.; Ganne-Carrie, N.; Trinchet, J.C.; Vicaut, E.; Beaugrand, M. Effect of long-term propranolol treatment on hepatocellular carcinoma incidence in patients with hcv-associated cirrhosis. Cancer Prev. Res. 2012, 5, 1007-1014. [CrossRef] [PubMed]

26. Choi, C.H.; Song, T.; Kim, T.H.; Choi, J.K.; Park, J.Y.; Yoon, A.; Lee, Y.Y.; Kim, T.J.; Bae, D.S.; Lee, J.W.; et al. Meta-analysis of the effects of beta blocker on survival time in cancer patients. J. Cancer Res. Clin. Oncol. 2014, 140, 1179-1188. [CrossRef] [PubMed]

27. Childers, W.K.; Hollenbeak, C.S.; Cheriyath, P. Beta-blockers reduce breast cancer recurrence and breast cancer death: A meta-analysis. Clin. Breast Cancer 2015, 15, 426-431. [CrossRef] [PubMed]

28. Giampieri, R.; Scartozzi, M.; del Prete, M.; Faloppi, L.; Bianconi, M.; Ridolfi, F.; Cascinu, S. Prognostic value for incidental antihypertensive therapy with beta-blockers in metastatic colorectal cancer. Medicine (Baltimore) 2015, 94, e719. [CrossRef] [PubMed]

29. Watkins, J.L.; Thaker, P.H.; Nick, A.M.; Ramondetta, L.M.; Kumar, S.; Urbauer, D.L.; Matsuo, K.; Squires, K.C.; Coleman, R.L.; Lutgendorf, S.K.; et al. Clinical impact of selective and nonselective beta-blockers on survival in patients with ovarian cancer. Cancer 2015, 121, 3444-3451. [CrossRef] [PubMed]

30. Palm, D.; Lang, K.; Brandt, B.; Zaenker, K.S.; Entschladen, F. In vitro and in vivo imaging of cell migration: Two interdepending methods to unravel metastasis formation. Semin. Cancer Biol. 2005, 15, 396-404. [CrossRef] [PubMed]

31. Kim, B.J.; Hannanta-anan, P.; Chau, M.; Kim, Y.S.; Swartz, M.A.; Wu, M. Cooperative roles of SDF-1 $\alpha$ and EGF gradients on tumor cell migration revealed by a robust 3D microfluidic model. PLoS ONE 2013, 8, e68422. [CrossRef] [PubMed]

32. Jeon, J.S.; Bersini, S.; Gilardi, M.; Dubini, G.; Charest, J.L.; Moretti, M.; Kamm, R.D. Human 3D vascularized organotypic microfluidic assays to study breast cancer cell extravasation. Proc. Natl. Acad. Sci. USA 2015, 112, 214-219. [CrossRef] [PubMed]

33. Mosadegh, B.; Lockett, M.R.; Minn, K.T.; Simon, K.A.; Gilbert, K.; Hillier, S.; Newsome, D.; Li, H.; Hall, A.B.; Boucher, D.M.; et al. A paper-based invasion assay: Assessing chemotaxis of cancer cells in gradients of oxygen. Biomaterials 2015, 52, 262-271. [CrossRef] [PubMed] 
34. Pantziarka, P.; Bouche, G.; Meheus, L.; Sukhatme, V.; Sukhatme, V.P.; Vikas, P. The repurposing drugs in oncology (redo) project. Ecancermedicalscience 2014, 8, 442. [CrossRef] [PubMed]

35. Azuma, H.; Inamoto, T.; Sakamoto, T.; Kiyama, S.; Ubai, T.; Shinohara, Y.; Maemura, K.; Tsuji, M.; Segawa, N.; Masuda, H.; et al. Gamma-aminobutyric acid as a promoting factor of cancer metastasis; induction of matrix metalloproteinase production is potentially its underlying mechanism. Cancer Res. 2003, 63, 8090-8096. [PubMed]

36. Zhang, D.; Li, X.; Yao, Z.; Wei, C.; Ning, N.; Li, J. Gabaergic signaling facilitates breast cancer metastasis by promoting erk1/2-dependent phosphorylation. Cancer Lett. 2014, 348, 100-108. [CrossRef] [PubMed]

37. Ortega, A. A new role for gaba: Inhibition of tumor cell migration. Trends Pharmacol. Sci. 2003, 24, 151-154. [CrossRef]

38. Neman, J.; Termini, J.; Wilczynski, S.; Vaidehi, N.; Choy, C.; Kowolik, C.M.; Li, H.; Hambrecht, A.C.; Roberts, E.; Jandial, R. Human breast cancer metastases to the brain display gabaergic properties in the neural niche. Proc. Natl. Acad. Sci. USA 2014, 111, 984-989. [CrossRef] [PubMed]

39. Medinger, M.; Halter, J.; Heim, D.; Buser, A.; Gerull, S.; Stern, M.; Passweg, J. Angiogenic markers in plasma cell myeloma patients treated with novel agents. Anticancer Res. 2015, 35, 1085-1090. [PubMed]

40. Vargesson, N. Thalidomide-induced teratogenesis: History and mechanisms. Birth Defects Res. C Embryo Today 2015, 105, 140-156. [CrossRef] [PubMed]

41. Beedie, S.L.; Peer, C.J.; Pisle, S.; Gardner, E.R.; Mahony, C.; Barnett, S.; Ambrozak, A.; Gutschow, M.; Chau, C.H.; Vargesson, N.; et al. Anticancer properties of a novel class of tetrafluorinated thalidomide analogues. Mol. Cancer Ther. 2015, 14, 2228-2237. [CrossRef] [PubMed]

42. Joseph, J.; Niggemann, B.; Zaenker, K.S.; Entschladen, F. Anandamide is an endogenous inhibitor for the migration of tumor cells and tlymphocytes. Cancer Immunol. Immunother. 2004, 53, 723-728. [CrossRef] [PubMed]

43. Schaap-Nutt, A.; Thyssen, D.A.; Drell, D.W.; Entschladen, F. Anti-metastatics: An overview of drug candidates in current pipelines. Curr. Pharm. Des. 2014, 20, 6522-6528. [CrossRef] [PubMed]

44. Sorlie, T.; Perou, C.M.; Tibshirani, R.; Aas, T.; Geisler, S.; Johnsen, H.; Hastie, T.; Eisen, M.B.; van de Rijn, M.; Jeffrey, S.S.; et al. Gene expression patterns of breast carcinomas distinguish tumor subclasses with clinical implications. Proc. Natl. Acad. Sci. USA 2001, 98, 10869-10874. [CrossRef] [PubMed]

45. Masur, K.; Lang, K.; Niggemann, B.; Zaenker, K.S.; Entschladen, F. High PKC alpha and low E-cadherin exporession contribute to high migratory activity of colon carcinoma cells. Mol. Biol. Cell 2001, 12, 1973-1982. [CrossRef] [PubMed]

46. Niggemann, B.; Drell, T.L.; Joseph, J.; Weidt, C.; Lang, K.; Zaenker, K.S.; Entschladen, F. Tumor cell locomotion: Differential dynamics of spontaneous and induced migration in a 3D collagen matrix. Exp. Cell Res. 2004, 298, 178-187. [CrossRef] [PubMed]

(C) 2016 by the authors; licensee MDPI, Basel, Switzerland. This article is an open access article distributed under the terms and conditions of the Creative Commons by Attribution (CC-BY) license (http:/ / creativecommons.org/licenses/by/4.0/). 